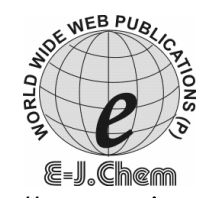

http://www.e-journals.net

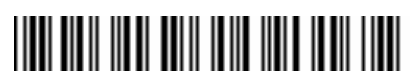

ISSN: 0973-4945; CODEN ECJHAO

E-Journal of Chemistry

Vol. 5, No.3, pp. 627-633, July 2008

\title{
Synthetic, Spectral and Thermal Studies of Tin(IV) Complexes of 1, 5-Benzodiazepines
}

\author{
SURESH $^{\#}$, PADAKI SRINIVAS $\ddagger$, T. SURESH ${ }^{\dagger}$, \\ M. REVANASIDDAPPA ${ }^{* \S}$ and SYED KHASIM ${ }^{\mathbb{T}}$ \\ ${ }^{\#}$ Department of Applied Science and Biotechnology, \\ Bellary Engineering College, Bellary - 583 104, Karnataka, India. \\ ‡Department of Chemistry, P.D.A. College of Engineering, \\ Gulbarga - 585 102, Karnataka, India. \\ †Department of Industrial Chemistry, Gulbarga University Post Graduate Centre, \\ Vinayaka Nagar, Cantonment, Bellary- 583 104, Karnataka, India.

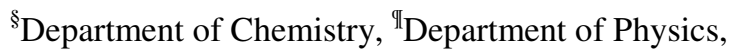 \\ PES School of Engineering,Hosur Road, Bangalore- 560100 Karnataka, India. \\ revum@ rediffmail.com
}

Received 12 October 2007; Accepted 22 December 2007

\begin{abstract}
Tin(IV) complexes of 7-substituted 6,7-benzo-1,5-dizepines have been synthesized in absolute alcoholic medium. Elemental analysis indicates that the complexes have 1:2 stoichiometry of the type $\mathrm{L}_{2} \mathrm{SnCl}_{4}$, TGA data support this conclusion. Molar conductance values in DMF at $10^{-3} \mathrm{M}$ suggest that, these complexes are non-electrolytes. Infrared spectral data shows the involvement of $\mathrm{C}=\mathrm{N}$ and $\mathrm{NH}$ groups in coordination with the metal ion. X-ray diffraction pattern of few representative complexes indicate that, these are having simple cubic crystal structure. The energy of activation and order of reaction are calculated using TGA data of the complexes. All these information support that $\mathrm{Sn}(\mathrm{IV})$ in these complexes exhibits coordination number eight.
\end{abstract}

Keywords: Thermal studies, Benzodiazepines, Electronic spectra.

\section{Introduction}

Tin is a toxic metal ${ }^{1}$. The effective antidotes tried to remove toxic metals from human body involves chelating agents ${ }^{1,2}$. Benzodiazepines are well known for their complexing capabalities $^{3-7}$. A few transition metal complexes of 1,4-benzodiazepines have been reported $^{1-4}$ hitherto. We have reported a few transition metal complexes of 1,5benzodiazepines ${ }^{8,9}(\mathrm{DMBDA})$. There is no report on the synthesis and characterization of $\operatorname{tin}^{\mathrm{IV}}$ complexes of benzodiazepines. In this paper we report the synthesis, characterization and thermal studies of Tin(IV) complexes with the following benzodiazepines. 


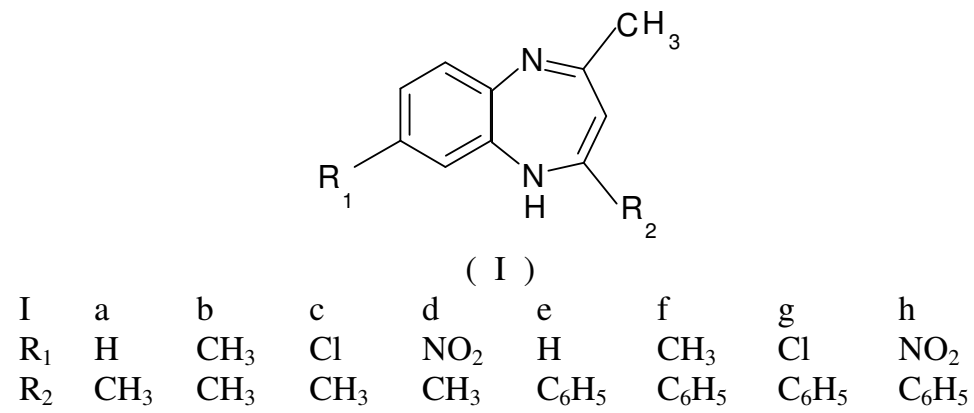

\section{Experimental}

\section{Materials and methods}

The chemicals used to prepare the ligands were of reagent grade. Substituted DMBDA were prepared using Thiele and Stimmig method ${ }^{9}$. Tin(IV) chloride from E-Merck was used without further purification.

\section{Preparation of the complexes}

To a solution of $0.01 \mathrm{M}$ of the ligand in $25 \mathrm{~mL}$ dry ethyl alcohol was added with $0.005 \mathrm{M}$ Tin(IV) chloride with constant stirring. The reaction mixture was stirred for half an hour and the complex separated was filtered, washed with ethyl alcohol and ether and dried over fused calcium chloride. The dried complex was powdered and purified by extracting in Soxhlet thimble using dry ethyl alcohol.

\section{Elemental analysis}

Tin(IV) and chloride in the complexes were estimated gravimetrically ${ }^{10}$. The nitrogen was determined by Dumas method ${ }^{10}$.

\section{Physical measurements}

The molar conductance measurements at the complexes were made on Elico CL-24 Conductivity Bridge with cell of cell constant 0.1 . The infrared spectra of the ligands and their complexes were recorded on a Hitachi 290 spectrophotometer in the region $4000-250 \mathrm{~cm}^{-1}$. The electronic spectra were taken with a Shimadzu UV-160A spectrophotometer and X-ray diffraction on PW1820 diffractometer with Cu LEF 40KV, 30mA X-ray tube in the 'd' value range o $1.5406-14.7184$.

\section{Results and Discussion}

The elemental analysis (Table 1) conforms to the formation of 1:2 complexes of the type $\mathrm{Cl}_{4} \mathrm{Sn}(\mathrm{DMBDA})_{2}$. The molar conductance values of the complexes (Table 2) in DMF at $10^{-3} \mathrm{M}$ concentration are too low to account for any dissociation. Hence, these complexes are regarded as non-electrolytes in DMF.

\section{IR spectra}

Important infrared frequencies of the ligands, complexes and their assignments are set out in Table $3 \& 4$. In the IR spectra of ligands, a broad band of medium intensity around $3350 \mathrm{~cm}^{-1}$ has been assigned to $v(\mathrm{NH})$ vibrations in view of the previous reports ${ }^{11}$. A high intensity band at $1580 \mathrm{~cm}^{-1}$ and bands in the $1225-960$ and $750-650 \mathrm{~cm}^{-1}$ regions have been assigned to $v(\mathrm{C}=\mathrm{N})$, aromatic inplane and outplane vibrations respectively on analogy with previous assignments $^{11-15}$. 
Table 1. Analytical data of complexes

\begin{tabular}{cccccc}
\hline \multirow{2}{*}{ Complex } & \multirow{2}{*}{ Empirical formula } & \multicolumn{4}{c}{ \% Analysis, Found/ (Calcd.) } \\
\cline { 3 - 6 } & & Nitrogen & Carbon & Chlorine & Tin \\
\hline \multirow{2}{*}{$(\mathrm{Ia})_{2} \mathrm{SnCl}_{4}$} & $\left(\mathrm{C}_{11} \mathrm{H}_{12} \mathrm{~N}_{2}\right)_{2} \mathrm{SnCl}_{4}$ & 9.29 & 43.01 & 24.51 & 19.50 \\
& & $(9.30)$ & $(43.00)$ & $(24.80)$ & $(19.30)$ \\
$(\mathrm{Ib})_{2} \mathrm{SnCl}_{4}$ & $\left(\mathrm{C}_{12} \mathrm{H}_{13} \mathrm{~N}_{2}\right)_{2} \mathrm{SnCl}_{4}$ & $(8.86$ & 45.87 & 22.87 & 18.67 \\
& & 8.32 & $(46.00)$ & $(23.00)$ & $(18.90)$ \\
$(\mathrm{Ic})_{2} \mathrm{SnCl}_{4}$ & $\left(\mathrm{C}_{11} \mathrm{H}_{11} \mathrm{~N}_{2} \mathrm{Cl}\right)_{2} \mathrm{SnCl}_{4}$ & $(8.00)$ & $(40.40$ & 42.71 & 17.00 \\
& & 12.10 & 38.04 & $(42.90)$ & $(16.90)$ \\
$(\mathrm{Id})_{2} \mathrm{SnCl}_{4}$ & $\left(\mathrm{C}_{11} \mathrm{H}_{11} \mathrm{~N}_{3} \mathrm{O}_{2}\right)_{2} \mathrm{SnCl}_{4}$ & $(12.20)$ & $(38.40)$ & $(20.80$ & 17.00 \\
& & 7.69 & 52.55 & 19.61 & $16.80)$ \\
$(\mathrm{Ie})_{2} \mathrm{SnCl}_{4}$ & $\left(\mathrm{C}_{16} \mathrm{H}_{14} \mathrm{~N}_{2}\right)_{2} \mathrm{SnCl}_{4}$ & $(7.80)$ & $(52.40)$ & $(19.90)$ & $(16.20)$ \\
& & 7.41 & 53.97 & 18.78 & 15.61 \\
$(\mathrm{If})_{2} \mathrm{SnCl}_{4}$ & $\left(\mathrm{C}_{17} \mathrm{H}_{16} \mathrm{~N}_{2}\right)_{2} \mathrm{SnCl}_{4}$ & $(7.40)$ & $(54.00)$ & $(19.00)$ & $(15.40)$ \\
& & 7.03 & 48.18 & 35.63 & 14.80 \\
$(\mathrm{Ig})_{2} \mathrm{SnCl}_{4}$ & $\left(\mathrm{C}_{16} \mathrm{H}_{13} \mathrm{~N}_{2} \mathrm{Cl}_{2}\right)_{2} \mathrm{SnCl}_{4}$ & $(7.00)$ & $(48.40)$ & $(35.90)$ & $(14.50)$ \\
& & 10.27 & 46.94 & 17.36 & 14.42 \\
$(\mathrm{Ih})_{2} \mathrm{SnCl}_{4}$ & $\left(\mathrm{C}_{16} \mathrm{H}_{13} \mathrm{~N}_{3} \mathrm{O}_{2}\right)_{2} \mathrm{SnCl}_{4}$ & $(10.30)$ & $(46.80)$ & $(17.50)$ & $(14.40)$ \\
\hline
\end{tabular}

Table 2. Molar extinction coefficient data of complexes

\begin{tabular}{|c|c|c|c|}
\hline Complex & Empirical formula & $\lambda_{\max }, \mathrm{cm}^{-1}$ & $\begin{array}{c}\text { Molar extinction } \\
\text { coefficient }(\varepsilon), \text { L.mol }^{-1} \cdot \mathrm{cm}^{-1}\end{array}$ \\
\hline \multirow{4}{*}{ (Ia) $)_{2} \mathrm{SnCl}_{4}$} & \multirow{4}{*}{$\left(\mathrm{C}_{11} \mathrm{H}_{12} \mathrm{~N}_{2}\right)_{2} \mathrm{SnCl}_{4}$} & 16129 & 518 \\
\hline & & 17241 & 891 \\
\hline & & 19120 & 1223 \\
\hline & & 30675 & 1583 \\
\hline \multirow{3}{*}{$(\mathrm{Ib})_{2} \mathrm{SnCl}_{4}$} & \multirow{4}{*}{$\left(\mathrm{C}_{12} \mathrm{H}_{14} \mathrm{~N}_{2}\right)_{2} \mathrm{SnCl}_{4}$} & 15873 & 418 \\
\hline & & 19157 & 1094 \\
\hline & & 20325 & 1690 \\
\hline \multirow{4}{*}{ (Ic) $)_{2} \mathrm{SnCl}_{4}$} & & 15385 & 300 \\
\hline & \multirow{3}{*}{$\left(\mathrm{C}_{11} \mathrm{H}_{11} \mathrm{~N}_{2} \mathrm{Cl}\right)_{2} \mathrm{SnCl}_{4}$} & 16260 & 450 \\
\hline & & 19231 & 780 \\
\hline & & 28571 & 2520 \\
\hline \multirow{4}{*}{$(\mathrm{Id})_{2} \mathrm{SnCl}_{4}$} & \multirow{4}{*}{$\left(\mathrm{C}_{11} \mathrm{H}_{11} \mathrm{~N}_{3} \mathrm{O}_{2}\right)_{2} \mathrm{SnCl}_{4}$} & 15152 & 218 \\
\hline & & 16393 & 420 \\
\hline & & 19380 & 740 \\
\hline & & 28011 & 2458 \\
\hline & & 16129 & 600 \\
\hline \multirow[t]{2}{*}{$(\mathrm{Ie})_{2} \mathrm{SnCl}_{4}$} & \multirow[t]{2}{*}{$\left(\mathrm{C}_{16} \mathrm{H}_{14} \mathrm{~N}_{2}\right)_{2} \mathrm{SnCl}_{4}$} & 19231 & 1323 \\
\hline & & 30303 & 1652 \\
\hline \multirow{3}{*}{ (If) ${ }_{2} \mathrm{SnCl}_{4}$} & \multirow{3}{*}{$\left(\mathrm{C}_{17} \mathrm{H}_{16} \mathrm{~N}_{2}\right)_{2} \mathrm{SnCl}_{4}$} & 19120 & 188 \\
\hline & & 31546 & 244 \\
\hline & & 16120 & 547 \\
\hline \multirow[t]{3}{*}{$(\mathrm{Ig})_{2} \mathrm{SnCl}_{4}$} & \multirow[t]{2}{*}{$\left(\mathrm{C}_{16} \mathrm{H}_{13} \mathrm{~N}_{2} \mathrm{Cl}\right)_{2} \mathrm{SnCl}_{4}$} & 19157 & 1025 \\
\hline & & 30120 & 2500 \\
\hline & \multirow{3}{*}{$\left(\mathrm{C}_{16} \mathrm{H}_{13} \mathrm{~N}_{3} \mathrm{O}_{2}\right)_{2} \mathrm{SnCl}_{4}$} & 16393 & 523 \\
\hline \multirow{2}{*}{ (Ih) $)_{2} \mathrm{SnCl}_{4}$} & & 19608 & 815 \\
\hline & & 29412 & 2580 \\
\hline
\end{tabular}


Table 3. Important infrared frequencies of ligands and their assignments

\begin{tabular}{|c|c|c|c|c|c|c|}
\hline S. No. & Ligand & $v(\mathrm{NH})$ & $v(\mathrm{NH})$ & $v(\mathrm{C}=\mathrm{C})$ & $v(\mathrm{C}=\mathrm{N})$ & $v(\mathrm{C}=\mathrm{C})$ Aromatic \\
\hline 01 & Ia & $\begin{array}{l}3500 \mathrm{~b} \\
3350 \mathrm{~b}\end{array}$ & $\begin{array}{l}3050 \mathrm{~s} \\
2980 \mathrm{~s}\end{array}$ & $1650 \mathrm{~s}$ & $1630 \mathrm{~m}$ & $\begin{array}{c}1570 \mathrm{~m} \\
1540 \mathrm{sh} \\
1520 \mathrm{~s}\end{array}$ \\
\hline 02 & $\mathrm{Ib}$ & $\begin{array}{l}3500 \mathrm{~b} \\
3400 \mathrm{~b}\end{array}$ & $\begin{array}{l}3050 \mathrm{~s} \\
2980 \mathrm{~s}\end{array}$ & $1660 \mathrm{~m}$ & $1640 \mathrm{~m}$ & $\begin{array}{c}1580 \mathrm{~m} \\
1540 \mathrm{sh} \\
1520 \mathrm{~s}\end{array}$ \\
\hline 03 & Ic & $\begin{array}{l}3500 \mathrm{~b} \\
3400 \mathrm{~b}\end{array}$ & $\begin{array}{l}3040 \mathrm{~s} \\
2980 \mathrm{~s}\end{array}$ & $1660 \mathrm{~m}$ & $1640 \mathrm{~m}$ & $\begin{array}{c}1580 \mathrm{~m} \\
1520 \mathrm{~s}\end{array}$ \\
\hline 04 & Id & $\begin{array}{l}3500 \mathrm{~b} \\
3350 \mathrm{~b} \\
3450 \mathrm{~b}\end{array}$ & $\begin{array}{l}3000 \mathrm{~s} \\
2980 \mathrm{~s}\end{array}$ & $1660 \mathrm{~s}$ & $1620 \mathrm{~m}$ & $\begin{array}{l}1580 \mathrm{~m} \\
1560 \mathrm{sh} \\
1520 \mathrm{~s}\end{array}$ \\
\hline 05 & Ie & $\begin{array}{l}3500 \mathrm{~b} \\
3400 \mathrm{~b} \\
3350 \mathrm{~b}\end{array}$ & $\begin{array}{l}3050 \mathrm{~s} \\
2980 \mathrm{~s}\end{array}$ & $1650 \mathrm{~s}$ & $1630 \mathrm{~m}$ & $\begin{array}{l}1570 \mathrm{~s} \\
1540 \mathrm{~s} \\
1520 \mathrm{~s}\end{array}$ \\
\hline 06 & If & $\begin{array}{l}3500 \mathrm{~b} \\
3400 \mathrm{~b}\end{array}$ & $\begin{array}{l}3050 \mathrm{~s} \\
2980 \mathrm{~s}\end{array}$ & $1660 \mathrm{~s}$ & $1640 \mathrm{~m}$ & $\begin{array}{l}1580 \mathrm{~m} \\
1520 \mathrm{~s} \\
1540 \mathrm{~s}\end{array}$ \\
\hline 07 & Ig & $\begin{array}{l}3500 \mathrm{~b} \\
3450 \mathrm{~b}\end{array}$ & $\begin{array}{l}3040 \mathrm{~s} \\
2980 \mathrm{~s}\end{array}$ & $1660 \mathrm{~s}$ & $1640 \mathrm{~s}$ & $\begin{array}{c}1570 \mathrm{~m} \\
1520 \mathrm{~s}\end{array}$ \\
\hline 08 & Ih & $\begin{array}{l}3500 \mathrm{~b} \\
3450 \mathrm{~b}\end{array}$ & $\begin{array}{l}3000 \mathrm{~s} \\
2980 \mathrm{~s}\end{array}$ & $1660 \mathrm{~s}$ & $1620 \mathrm{~m}$ & $\begin{array}{l}1580 \mathrm{~m} \\
1560 \mathrm{w} \\
1520 \mathrm{~s}\end{array}$ \\
\hline
\end{tabular}

$b=$ broad, $s=$ sharp, $m=$ medium, $s h=$ shoulder,$w=$ weak

Table 4. Important infrared frequencies of few representative complexes and their assignments.

\begin{tabular}{|c|c|c|c|c|c|c|}
\hline Complex & $v(\mathrm{NH})$ & $v(\mathrm{C}=\mathrm{C})$ & $v(\mathrm{C}=\mathrm{N})$ & $v(\mathrm{C}=\mathrm{C})$ Aromatic & $v(\mathrm{M}-\mathrm{N})$ & $v(\mathrm{M}-\mathrm{Cl})$ \\
\hline (Ia) $)_{2} \mathrm{SnCl}_{4}$ & $\begin{array}{l}3320 \mathrm{~s} \\
3250 \mathrm{~m}\end{array}$ & $1630 \mathrm{~s}$ & $1600 \mathrm{~s}$ & $\begin{array}{l}1570 \mathrm{~s} \\
1510 \mathrm{~s}\end{array}$ & $\begin{array}{l}570 \mathrm{w} \\
530 \mathrm{w} \\
505 \mathrm{w} \\
480 \mathrm{w} \\
460 \mathrm{w}\end{array}$ & $\begin{array}{l}300 \mathrm{sh} \\
285 \mathrm{sh}\end{array}$ \\
\hline$(\mathrm{Ib})_{2} \mathrm{SnCl}_{4}$ & $\begin{array}{l}3270 \mathrm{~s} \\
3200 \mathrm{w}\end{array}$ & $1610 \mathrm{~s}$ & $1600 \mathrm{~s}$ & $\begin{array}{l}1560 \mathrm{sh} \\
1540 \mathrm{sh}\end{array}$ & $\begin{array}{c}580 \mathrm{~s} \\
540 \mathrm{w} \\
520 \mathrm{w} \\
580 \mathrm{w} \\
470 \mathrm{~s} \\
450 \mathrm{~s}\end{array}$ & $\begin{array}{l}300 \mathrm{~s} \\
290 \mathrm{~s}\end{array}$ \\
\hline (Ic) $)_{2} \mathrm{SnCl}_{4}$ & $\begin{array}{c}3250 \mathrm{~b} \\
3150 \mathrm{bw}\end{array}$ & $1620 \mathrm{~s}$ & $1685 \mathrm{sh}$ & $\begin{array}{l}1680 \mathrm{~s} \\
1560 \mathrm{w}\end{array}$ & $\begin{array}{l}580 \mathrm{~s} \\
560 \mathrm{w} \\
500 \mathrm{w} \\
480 \mathrm{~s} \\
430 \mathrm{~s}\end{array}$ & $\begin{array}{l}300 \mathrm{~s} \\
290 \mathrm{~s}\end{array}$ \\
\hline (Ih) $)_{2} \mathrm{SnCl}_{4}$ & $\begin{array}{l}3200 \mathrm{bw} \\
3100 \mathrm{bw}\end{array}$ & $1520 \mathrm{sh}$ & $1590 \mathrm{~s}$ & $\begin{array}{l}1580 \mathrm{~s} \\
1500 \mathrm{~s}\end{array}$ & $\begin{array}{c}580 \mathrm{~s} \\
575 \mathrm{w} \\
480 \mathrm{~s} \\
475 \mathrm{~s} \\
425 \mathrm{~s}\end{array}$ & $\begin{array}{l}300 \mathrm{~s} \\
290 \mathrm{~s}\end{array}$ \\
\hline
\end{tabular}

$b=$ broad,$s=$ sharp,$m=$ medium, sh $=$ shoulder,$w=$ weak 
In the infrared spectra of complexes the following changes are observed. The band due to $v(\mathrm{NH})$ shifts and appears in the region $3320-3100 \mathrm{~cm}^{-1}$ as a medium intensity split band. Coordination of $-\mathrm{NH}$ group to the metal increases the multiplicity associated with nitrogen and thus results in splitting and shifting of the band ${ }^{13}$. In the present context the $\mathrm{NH}$ vibration show a low frequency shift compared with the ligands. The $v(C=N)$ band appears in the region $1570-1600 \mathrm{~cm}^{-1}$ as high intensity band indicating that, the $\mathrm{C}=\mathrm{N}$ group is involved in coordination with $\operatorname{tin}^{\mathrm{IV}}$ through nitrogen. Coordination of these groups to the metal ion leaves the nitrogen atom partially positively charged, resulting in mobolising $\pi$ electron density associated with $\mathrm{C}=\mathrm{C}$ consequently affecting the bond order. As a result of this $v(C=C)$ appears around $1640 \mathrm{~cm}^{-1}$ as a band of varying intensity.

In addition to these changes, we observe medium intensity bands in the region 570-425 $\mathrm{cm}^{-1}$ attributable to $v(\mathrm{Sn}-\mathrm{N})$ vibrations coupled with $v$ (ligand) vibration. The bands appearing in the region $470-425 \mathrm{~cm}^{-1}$ are regarded as due to $v(\mathrm{Sn}-\mathrm{N})$ vibrations. The medium intensity bands in the region $285-300 \mathrm{~cm}^{-1}$ are assigned to $v(\mathrm{Sn}-\mathrm{Cl})$ vibrations. The assignments made in these regions are purely tentative and based on the previous reports ${ }^{5-7,15}$.

\section{Electronic spectra}

The electronic spectra were taken in DMF at $10^{-3} \mathrm{M}$ concentration. The spectra are characterized by two bands in the region $20,000-33,333 \mathrm{~cm}^{-1}$ and are attributed to $\pi-\pi$ transitions ${ }^{16}$. In the spectra of complexes, the ligand bands are replaced by high intensity broad bands. In addition to the usual bands of the ligands, the high intensity band is observed around $29,411 \mathrm{~cm}^{-1}$ and attributed to metal-ligand charge transfer band ${ }^{16}$. Appearance of this band confirms the formation of complexes.

\section{$X$-ray (powder) diffraction}

The powder diffraction of selected complexes have been indexed for simple cubic systems and the observed $\sin ^{2} \theta, d$-values together with $\mathrm{h}, \mathrm{k}, 1$ and ' $\mathrm{a}$ ' values are set out in Table 5 . The values obtained for unit cell parameters $\mathrm{a}, \mathrm{b}$ and $\mathrm{c}$ remain almost constant indicating viz., $\mathrm{a}=\mathrm{b}=\mathrm{c}$. This is the condition for simple cubic system.

\section{Thermal studies}

Thermograms obtained for a few complexes have been recorded and the data are summarized in Table 6. The thermogram for complex Ig shows four breaks. A gradual loss in the weight is observed from $255-325^{\circ} \mathrm{C}$ and the loss is about $8.59 \%$. This computes to the loss of two of the four chlorides. The second weight loss is observed from $325-350^{\circ} \mathrm{C}$ and the per cent of weight loss is 8.59 which corresponds to the elimination of remaining two chlorides. Further, a steep decrease in the weight of $35.17 \%$ in the temperature range of $350-430^{\circ} \mathrm{C}$ is attributed to the oxidation of the ligand moiety. After this temperature there is no weight loss, as the formed species is thermally stable. The weight calculations agree well with the formation of $\mathrm{SnO}_{2}$.

Table 5. X-ray (powder) diffraction data

\begin{tabular}{ccccccc}
\hline Complex & $\mathrm{d}$ & $\operatorname{Sin}^{2} \theta$ & $\mathrm{N}$ & $\mathrm{hkl}$ & $\mathrm{a}$ & $\begin{array}{c}\text { Crystal } \\
\text { structure }\end{array}$ \\
\hline & 5.71 & 0.135 & 2 & 110 & 8.075 & \\
$(\mathrm{Ig})_{2} \mathrm{SnCl}_{4}$ & 3.95 & 0.197 & 4 & 200 & 7.900 & Simple \\
& 3.15 & 0.227 & 5 & 210 & 7.600 & cubic \\
& & 0.248 & 6 & 211 & 7.710 & \\
\hline
\end{tabular}


Table 6. Thermo gravimetric data of complexes

\begin{tabular}{|c|c|c|c|c|c|c|}
\hline \multirow{2}{*}{ Complex } & \multirow{2}{*}{ Temp. } & \multicolumn{2}{|c|}{ Loss in weight } & \multirow{2}{*}{$\begin{array}{c}\mathrm{E}^{0} \\
\text { K. Cal }\end{array}$} & \multirow{2}{*}{$\begin{array}{l}\text { Order of } \\
\text { Reaction }\end{array}$} & \multirow{2}{*}{ Inference } \\
\hline & & Found & Calculated & & & \\
\hline \multirow{4}{*}{$(\mathrm{Ia})_{2} \mathrm{SnCl}_{4}$} & 623 & 12.07 & 11.75 & \multirow{4}{*}{34} & \multirow{4}{*}{2.2} & Loss due to $\mathrm{Cl}_{2}$ \\
\hline & 673 & 12.07 & 11.75 & & & Loss due to another $\mathrm{Cl}_{2}$ \\
\hline & 798 & 27.45 & 28.48 & & & Loss due to ligand \\
\hline & 998 & 14.94 & 15.37 & & & $\begin{array}{l}\text { Loss due to sublimation } \\
\text { of } \mathrm{SnO}_{2}\end{array}$ \\
\hline \multirow{4}{*}{$(\mathrm{Ig})_{2} \mathrm{SnCl}_{4}$} & 598 & 8.59 & 8.91 & \multirow{4}{*}{23} & \multirow{4}{*}{1.2} & Loss due to $\mathrm{Cl}_{2}$ \\
\hline & 618 & 8.59 & 8.91 & & & $\begin{array}{l}\text { Loss due to ligand } \\
\text { Lend }\end{array}$ \\
\hline & $\begin{array}{l}703 \\
096\end{array}$ & 33.59 & 33.69 & & & Loss due to sublimation \\
\hline & 996 & 12.19 & 11.65 & & & of $\mathrm{SnO}_{2}$ \\
\hline
\end{tabular}

The complex Ia lost the weight between $100^{\circ}$ and $235^{\circ} \mathrm{C}$. The weight loss is gradual. In $235^{\circ}-350^{\circ} \mathrm{C}$ range the complex shows the steep decrease in the weight. This is due to the elimination of two chlorides. The other two chlorides are eliminated between $350-400^{\circ} \mathrm{C}$ and the oxidation of the ligand in $400-560^{\circ} \mathrm{C}$ with the formation of $\mathrm{SnO}_{2}$. The percentage loss of weight is in accordance with the suggested empirical formula of the complexes.

The Freeman and Corroll ${ }^{17}$ equation has been deployed to evaluate order of reaction and energy of activation from thermograms.

$$
\text { A plot of } \frac{\Delta \log \mathrm{dw} / \mathrm{dt}}{\Delta \log \mathrm{Wr}} v s \frac{\Delta\left(\mathrm{T}^{-1}\right)}{\Delta \log \mathrm{Wr}} \text { gives a straight line with a slope } \pm \mathrm{E}^{*} / 2.303 \mathrm{R}
$$

and intercept is $-\mathrm{x}$.

Where, $\mathrm{W}=$ weight loss up to time $\mathrm{t}, \mathrm{Wr}=(\mathrm{Wc}-\mathrm{W})$ difference of weight loss between completing of reaction up to time $\mathrm{t}, \mathrm{E}=$ energy of activation, $\mathrm{X}=$ order of reaction and $\mathrm{T}=$ absolute temperature.

The $\mathrm{dw}$ and $\mathrm{Wr}$ for the purpose of plot can be directly determined from thermograms. Intercepts directly gives order of reaction, and using $\mathrm{R}$ gas constant, slope can be calculated. The values of order of reaction and energy of activation are shown in Table 5. The high values of energy of activation obtained for these complexes are suggestive of their stability.

On the basis of elemental analysis, spectral and thermal studies the following structure may be assigned to the $\mathrm{Cl}_{4} \mathrm{Sn}(\mathrm{DMBDA})_{2}$ :<smiles>[R]c1ccc2c(c1)NC(S(Cl)(Cl)(Cl)(Cl)n1cc([R])c([R])c1)NC2</smiles> 


\section{Acknowledgement}

The authors are thankful to Dr. Yashwanth Bhupal, Principal, Bellary Engineering Collage, Bellary and the President of HKE'S Society and Principal, PDA Collage of Engineering, Gulbarga for the constant encouragement.

\section{References}

1. Sunderman F W, Arch. Ind. Health, 1958, 18, 480.

2. Volf V, Treatment of Incorporated Tansurenium Elements, Tech. Rep. Ser., 1978, 184, I.A.E.A. Vienna.

3. Ouchi A, Takeuchi T, Nakatini N and Takahashi Y, Bull. Chem. Soc. Japan, 1971,44, 434.

4. Hunter P W W and Webb G A, J. Inorg. Nucl. Chem., 1972, 34, 1511.

5. Preti C and Tosi G, J. Coord. Chem., 1976, 66, 81; J. Inorg. Nucl. Chem., 1979, 41, 263; Trans. Met. Chem., 1978, 3, 246.

6. Real R A, Munoz M N and Borras J, Thermochem Acta., 1986, 101, 83.

7. Real R A and Borras J, Synth. React. Inorg. Met. Org. Chem., 1984, 14, 843; 857; 1986, 16, 13.

8. Suresh, Prabhakar B K and Kulkarni V H , Indian J. Chem., 1990, 29A, 486.

9. Suresh, Prabhakar B K and Kulkarni V H, Asian J. Chem., 1991, 4, 210.

10. Vogel A I, A Text Book of Quantitative Inorganic Chemistry, $4^{\text {th }}$ Ed., 1978 William Clows Ltd., London.

11. Bellamy L J, Infrared Spectra of Organic Molecules, John Willey, New York, 1966.

12. Rassmussen R S, Tunicliff D D and Brattain R R, J. Am. Chem. Soc., 1949, 75, 2568.

13. Freeman N K, J. Am. Chem. Soc., 1953, 75, 1859.

14. Bush D H, and Bailer J C, J. Am. Chem. Soc., 1956, 78, 1137.

15. Bailer J C, Comprehensive Inorganic Chemistry, Pergamon Press, New York, 1978, 325.

16. Lever A B P, Inorganic Electronic Spectroscopy, Elsevier, Amsterdam, 1968.

17. Freeman E S and Carroll B, J. Phys. Chem., 1958, 42, 394. 


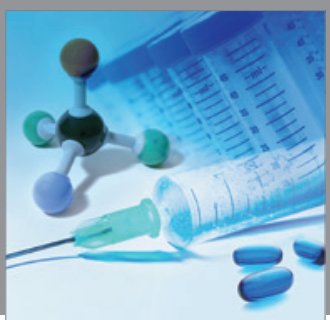

International Journal of

Medicinal Chemistry

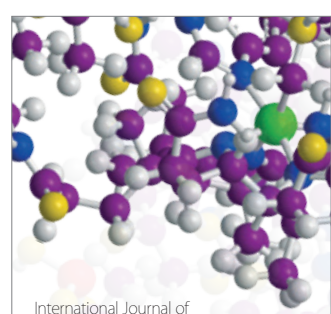

Carbohydrate Chemistry

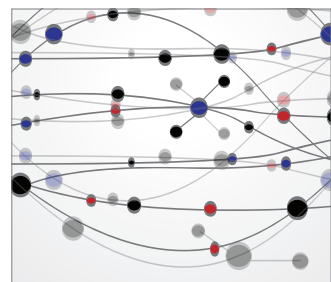

The Scientific World Journal
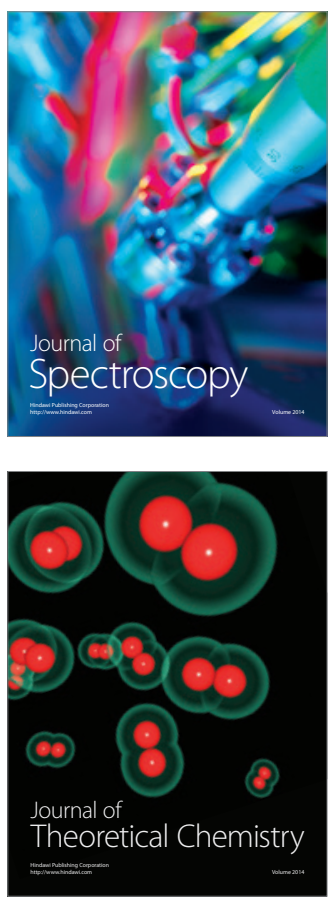
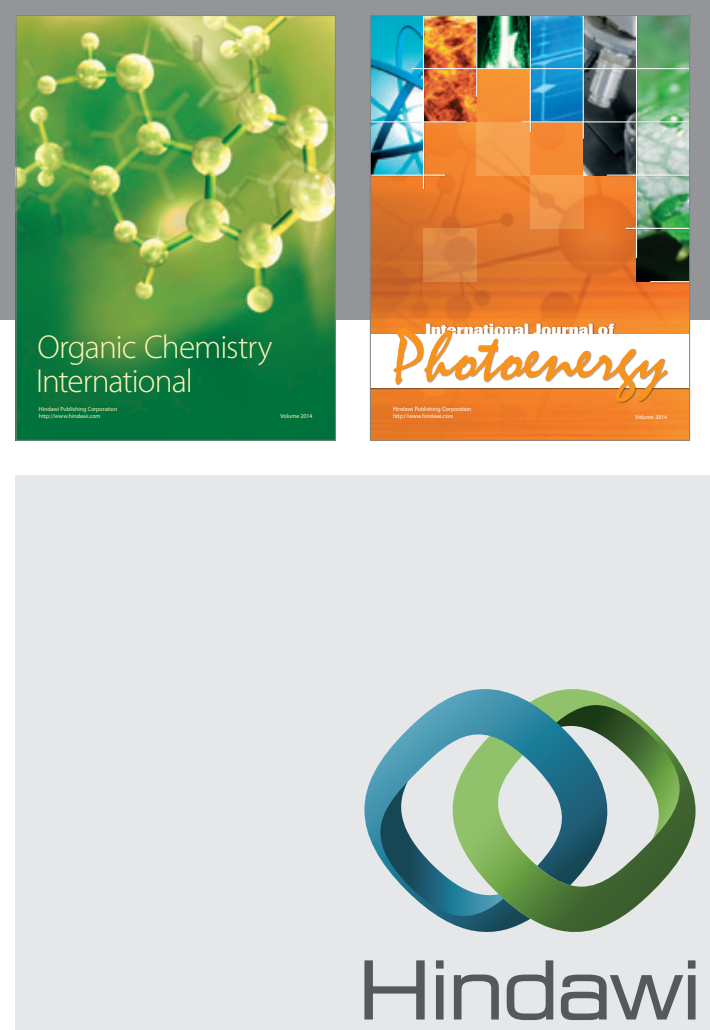

Submit your manuscripts at

http://www.hindawi.com
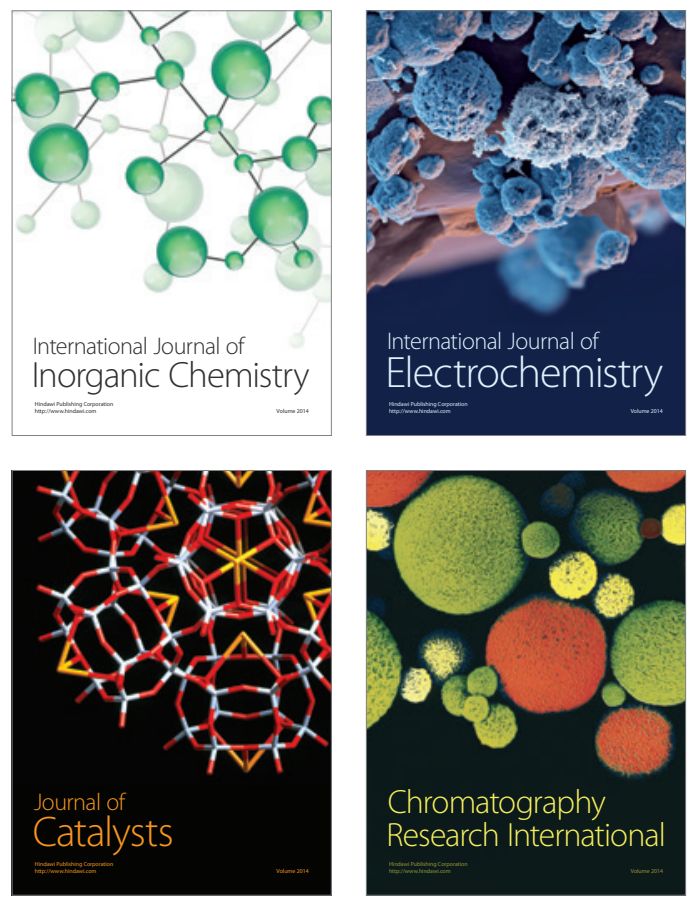
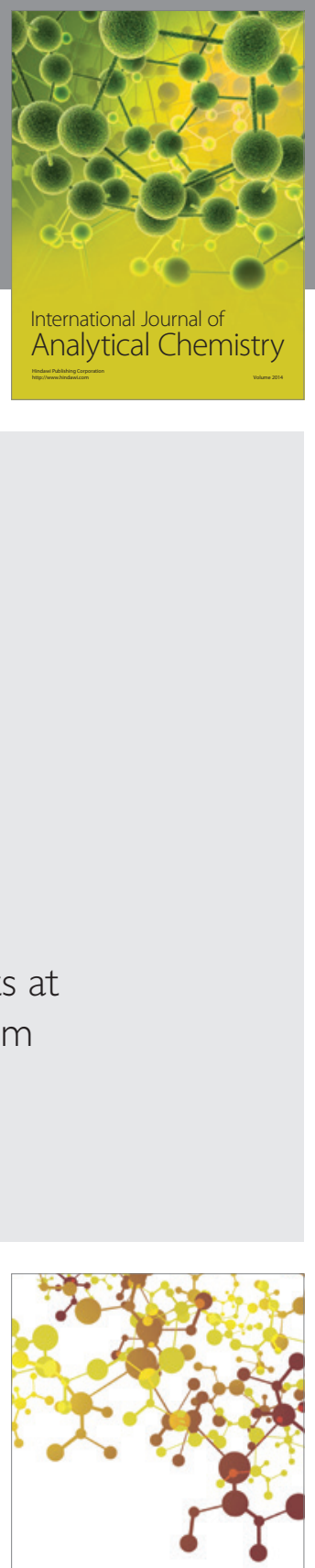

Journal of

Applied Chemistry
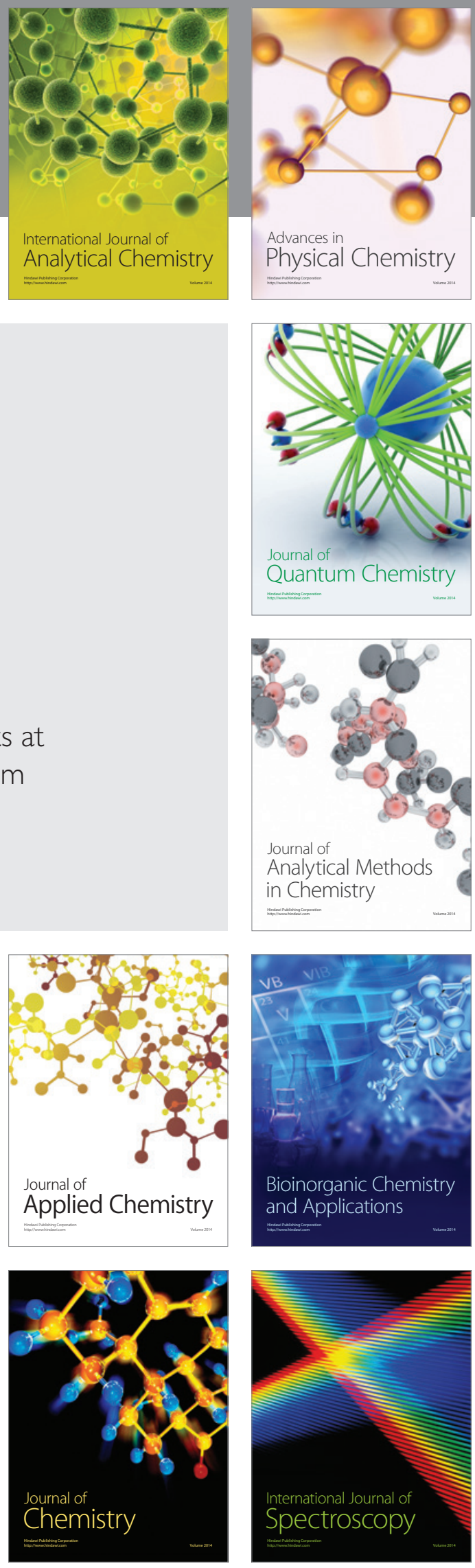